\title{
Web-Based Management Information System for Services Development: A Literature Review
}

\author{
Eny Setyawati ${ }^{1}$, Hasan Hariri ${ }^{2}$ \\ ${ }^{1}$ Student of Education Administration, Universitas Lampung, Bandar Lampung, Indonesia \\ ${ }^{2}$ Lecturer of Education Administration, Universitas Lampung, Bandar Lampung, Indonesia
}

\begin{abstract}
The development of internet technology and applications provides a good condition for establishing the scientific research management information system. Research on the influence of web-based management information systems for services development has been carried out in various organizations and in various countries. Web-based management information system is the right solution at this time. By using search and review methods, the review process began with a search engine, Google scholar and IEEE, to search for articles with keywords: "web-based management system information for services development". The conclusion of this literature review is that there is a positive and significant influence of web-based management information systems for services development and future research will help to help organizations evaluate the quality of their web-based services, design improvements and ultimately embed their websites into future services. This study includes many cases and the research findings apply only to the web-based management information system for services development. Web-based management information systems can be used to for various organizations and in various countries.
\end{abstract}

KEYWORDS: Web-Based, Management Information, Service Development

\section{INTRODUCTION}

In this revolution 4.0, everything needs fast access to build a system. Of course, adequate technology is needed to achieve this goal. Web-based management information system is the right solution at this time. The rapid development and advancement in technology require one to follow developments and progress. This development has been widely used by many parties. These developments and advancements also provide great opportunities for the efficient and accurate management and utilization of information (Noni, Ihsan, \& Ahmar, 2018). The development of internet technology and applications provides a good condition for establishing the scientific research management information system. Workflow technology is a kind of core technologies to realize business process automation. It can be combined with the application system effectively, and build the business management information system. Business process automation can significantly improve efficiency of the scientific research management (Liu, Yao, Zhang, Liu, \& Ding, 2015). Information technology cannot produce fast decision information without the presence of optimal hardware systems and software systems (Bahagia, Satria, \& Ahmadian, 2017).

Implemented technology will reduce the paths of the process stages of the work process, which was originally done manually, which is now replaced by information system. However, the use of such technology is the basis for the implementation of management information system (MIS) (Fauzy et al., 2018; Lazim et al., 2018). Management information system can using to improve the efficiency performance and the final stage of processing data into information that is distributed to the public is the interface. Therefore, the web is a popular information system interface that is easily accessible to the public today (Abdullah et al., 2018; Iskandar, Virma, \& Ahmar, 2019; Zulfan, Bahagia, Ahmadian, \& Satria, 2017).

The actual scope of the management information system includes three forming words: "management", "information", and "system". The management consists of processes or activities carried out by company managers such as plan (set strategy, goals and direction actions), organizing, initiating, coordinating and controlling operations to achieve predetermined goals. The information is the result of data processing obtained from each element of the system into a form that is easy to understand and is relevant knowledge needed by people to increase their understanding of the facts. Information for each element will differ from one another according to their respective needs. Finally, the system is a collection of elements that are interconnected with one another forming unity in the effort to achieve a purpose. So, management information system as information system that produces output using input and various processes needed to meet certain objectives in a management activity (Susanto, Mantja, Bafadal, \& Sonhadji, 2015). 


\section{International Journal of Current Science Research and Review}

ISSN: 2581-8341

Volume 04 Issue 03 March 2021

DOI: 10.47191/ijcsrr/V4-i3-05, Impact Factor: 5.825

IJCSRR@ 2021

WWw.ijcsrr.org

Several studies related to information technology such as information systems have been developed by previous researchers. Among several studies, there are information systems related to business such as business management information systems in terms of buying and selling community-generated plantation commodities (Satria, Zulfan, Yana, \& Yulizar, 2018). Management information systems (MIS) and technologies are used to leverage unique business competence, merge companies, restructure industries, and facilitate global competition. In addition, the research in western countries has shown that a great number of critical success factors significantly affect the contributions of information systems on business performance (Dong, Liu, \& Yin, 2008). For example, Beath (Lu et al., 2012) pointed out the significant role of IS managers support to IT champions; Janz and Prasarnphanich (LiKamWa, Liu, Lane, \& Zhong, 2013) described the importance of organizational learning.

The relation of management information systems (MIS) to company strategy and the attainment of competitive advantage has been the focus of many discussions during the past decade, and the importance of alignment between business strategy and MIS strategy is well recognized. From a contingency perspective, the change of environmental factors will impact business strategy and the alignment of MIS strategy to business strategy will determine MIS effectiveness and business performance. Previous empirical studies have shown that the alignment of MIS to business strategy and activities increases with the superior performance of the company. As part of business strategy, information system strategy helps firms implement strategic plans, achieve operational objectives, and gain competitive advantages in the end.

Website gives a pointer to the next stage in the evolution of public service websites. It supports a wide range of information, from local events and public health information to crime reports and discussion forums (King \& Brown, 2007). The challenges in measuring web-based service quality arise from differences between web-based and traditional customer service as well as the complementary functions of these two channels. Due to the growth of outsourcing, end-user-controlled information assets, joint ventures, and other alternative mechanisms by which organizations are meeting their needs for information system services, there has been a more pressing need to establish some means of measuring service quality and strategies to improve service quality. In particular, with the birth of the internet, large volumes of data demand effective statistical analysis (Li, Tan, \& Xie, 2002).

Web-based customer service can provide a close connection between customers and companies, and among the customers themselves. As a result, the opportunity for interaction with customers increases greatly (Reza Kiani, 1998). To increase great service development need some system which can support this purposes. A web information system is database-intensive and/or transaction intensive information system that is implemented and made accessible over the web by user access via web browsers or via mobile devices. In web information system, data is obtainable through web interfaces that are manifested in semi-structured document format including a navigation structure among the documents and pages organized into some kind of networks or hierarchy. Moreover, there are links to sites outside the system as well. Furthermore, there should also be services for retrieving and modifying data out of the system or from the underlying database (Molnár \& Ádám, 2019).

Unfortunately, at present it is evidence that the management information system for the service development still uses manual methods in many countries, particularly those in developing countries, including Indonesia. Therefore, there is a need to conduct research to help improve service development of a management information system that is needed to support services development Research question that guide this paper is: How are the influences of web-based management information system on service development?

\section{LITERATURE REVIEW}

\section{A. Web-Based Management Information System}

Information systems and technologies are used to leverage unique business competence, merge companies, restructure industries, and facilitate global competition. Numerous case studies on Chinese firms have shown that information systems could support sustainable development of companies. The application of information systems could optimize existing business processes and break through traditional business models. In addition, the research in western countries has shown that a great number of critical success factors significantly affect the contributions of information systems on business performance (Dong et al., 2008).

The information system is a combination of people, hardware, software, network communications, data sources, procedures and policies are well organized to store, organize again, store, and disseminate information of an organization (Anggadini, 2013). Management information systems a highly complex and delicate arena that calls for a lot of caution to be taken by its managers. It is for this reason that it is recommendable for organizations to ensure that they carefully select the individuals who are placed to control the systems (Nowduri, 2011). Management information system can also be used as decision makers for the leader in an organization 


\section{International Journal of Current Science Research and Review}

ISSN: 2581-8341

Volume 04 Issue 03 March 2021

DOI: 10.47191/ijesrr/V4-i3-05, Impact Factor: 5.825

IJCSRR@ 2021

www.ijcsrr.org

(Noni et al., 2018). To get good results from data processing, one way is by utilizing existing and developing technologies, or in other words, making a data processing system (Sumbaryadi \& Christo, 2019).

Information systems are a combination of information technology and the activities of people who use technology to support operations and management. Utilization of information in electronic form is now a part of people's modern lifestyles. This must be done to meet the demands on the quality of computer services, resource sharing, streamlining human resources, time efficiency and diversity of information managed (Afrina \& Ibrahim, 2012). The application of information technology as a means to store, obtain and disseminate scientific information in digital format, in a server computer that can be placed locally, or in a remote location, but can be accessed quickly and easily through a network. The form of application of information technology in this study is through SMS Gateway.

The application of information technology is influenced by several factors, namely: (a) ease of obtaining information technology products, (b) affordable prices for obtaining information technology products, (c) ability of information technology, (d) demands for public services that are all "clicked", (e) streamlining and simplifying work, (f) national, regional and global infrastructure development (Kosasish, 2009). The application of information technology can function in two forms, namely: The application of information technology used as an information system and the application of information technology as a means to store, obtain and disseminate scientific information in digital format (Afrina \& Ibrahim, 2015).

System is a collection of elements which interact to achieve certain goals. These components cannot be separated individually. The subsystems interact with each other and are interconnected to form a single unit so that the system's goals can be achieved. A system has certain characteristics components, system boundaries, environment outside the system, connectors, inputs, outputs, processors and goals (Wardana \& Aribowo, 2013). While, information system is a collection of objects, ideas, and their interrelations in achieving goals or objectives together. Information is data that has been organized into an appropriate form with the needs of someone, staff, manager, or other people in an organization or company. Source of information is data in the form of facts about objects, people expressed by value (Setiadi \& Muryanti, 2009).

The information system represents the structure of certain components of information processing systems, their relationships among components, those technological principles and directives of organization of which the main purpose is to support business. Webbased management information system is database-intensive and/or transaction intensive information system that is implemented and made accessible over the web by user access via web browsers or via mobile devices. In web information system, data is obtainable through web interfaces that are manifested in semi-structured document format including a navigation structure among the documents and pages organized into some kind of networks or hierarchy; moreover, there are links to sites outside the system as well (Molnár \& Ádám, 2019). Another reason web-based information systems are used is because of the ease in how to access them by accessing through an existing browser on a computer or telephone device (Suryandani, 2016). Furthermore, there should also be services for retrieving and modifying data out of the system or from the underlying database.

The role of information systems in helping organizations develop sustainability is very important and management information systems can contribute in this direction. Moreover, management decision assessment frameworks regarding the monitoring of protected areas always depend on the collected environmental data, processed and interpreted by the scientific staff. Consequently, the management information system can be utilized in fulfilling anticipated environmental objectives of an environmental organization by collecting, storing and processing multidimensional environmental records towards applying effective environmental management policies and planning strategies (Kouziokas, 2016; Standing, Jackson, Chen, Boudreau, \& Watson, 2008; Tomlinson, 2012)

To handle the complexity of changes and change management, some concepts are required namely the concept of the life history, the life cycle of systems, and the life history of entities or classes (of objects). We should use these concepts to distinguish between two behavioral aspects of web-based management information system. Life history of systems means the actual sequence of steps a system has gone or will go through during its lifetime, and life cycle seen as the finite set of generic phases and steps a system may go through over its entire life history (Noran, 2005). Web-based management information system has a static perspective representing the structural aspects at a specified point in time and a dynamic perspective capturing the various stages of architecture development that happens to a web-based management information system as an application system (Noran, 2003).

According to Dong et al.(2008), the alignment between information systems (IS) and business strategy along with its implications for perceived IS effectiveness and business performance is an important question, which is rarely studied in China. A structural equation 


\section{International Journal of Current Science Research and Review}

ISSN: 2581-8341

Volume 04 Issue 03 March 2021

DOI: 10.47191/ijesrr/V4-i3-05, Impact Factor: 5.825

IJCSRR@ 2021

www.ijcsrr.org

model was employed to test the conceptual model. Analyses of data gathered in a survey indicate that information system strategic alignment is a better predictor of business performance than business strategy or information system strategy alone, although business strategy can significantly influence business performance (Dong et al., 2008).

Based on an empirical study, this paper summarized the significance of IS strategic alignment and its impact on business performance. This study also measured business strategy, information system strategy, and information system strategic alignment, built a conceptual model to describe the relationship between these factors, and investigated their implications for information system performance and business performance.

\section{B. Services Development}

Services development is defined as innovations in new services or service procedures to achieve efficient operations and superior performance (Yang, Lee, \& Cheng, 2016). The development of information systems has an impact on all aspects, because existing competition demands to get the accuracy of information in all fields. This, of course, requires a development of services in an information system. Well implemented technology will reduce the path of the process stages of the work process, which was originally done manually, which is then replaced by the system (Fauzy et al., 2018; Lazim et al., 2018). Services development can be used to improve the efficiency performance and satisfaction of an organization. For example, Meriyanti (2013) and Fauzi (2016) built a webbased wedding organizer information system with structured approach method and prototype method; (Setiajati, 2017) designed the wedding organizer information service system with automatic package selection feature using Greedy algorithm; while Najiyah and Suharyanto (2017) created a wedding planner system information that became a place of all wedding organizer website (Boey, Ang, \& Liew, 2008). Of course, for example above we find that the study information system of web-based is useful to facilitate the service process.

Management and development perspective is placed in the foundation of the strategy map. The objectives that belong to this perspective influence directly the objectives that are included in the business process perspective. The availability of qualified and motivated staff as well as leadership commitment to the process of modernization and improvement is a precondition for administrations functional effectiveness and quality. Implementation of modern technologies and adoption of best practices in the internal business processes depends, to a large extent, on the employee qualification, perceptions and search for new knowledge and skills improvement. The entire process of renewal and development would be impossible without leadership support and vision on the need for improvement, resource supply and provision of appropriate work environment. The implementation of web-based management information system for service development will improve the administrative barriers, and ultimately will accelerate economic and social development (Gueorguiev, Dimitrova, Komitska, Traykov, \& Spassov, 2005).

The study of technology that can be used in problem solving is also carried out to ensure that systems are developed easily and meet system requirements. System requirements required by hardware and software, the system design process has been carried out. The development of services starts from a problem, objectives, objectivity, and finally scope (Fauzy et al., 2018). King and Brown (2007) conclude that The BRAIN website gives a pointer to the next stage in the evolution of public service websites. It supports a wide range of information, from local events and public health information to crime reports and discussion forums. It is a joint initiative between Brent council and local groups and so has the apparatus to tap into both the "wisdom" of the local community and the specialist expertise and resources of the council. Clearly, to achieve solutions that will endure, both parties need to be active and committed participants. According King and Brown researches we can find the result is the FMS developer also made the point that FMS can improve council efficiency by enabling posters (King \& Brown, 2007).

Every organization faces the challenge of integrating diverse IT systems. Developers must first solve communication-level integration issues, ensuring that systems using different transport protocols and data formats can exchange information. Once these issues are resolved, organizations must decide how their various IT systems can interact to support business processes. Using web services to expose applications over the Internet is now a widely accepted practice. Developers typically create web services individually and expose them either directly over the Internet or within an organization for particular purposes. (Pasley, 2005). Web services are emerging technologies that are changing the way people develop and use computer systems and software. Current web services testing techniques are unable to assure the desired level of trustworthiness, which presents a barrier to WS applications in mission and business critical environments. New assurance techniques are developed within the framework, including specification verification via completeness and consistency checking, specification refinement, distributed web services development, test case generation, and automated web services testing. Traditional test case generation methods only generate positive test cases that verify the functionality 


\section{International Journal of Current Science Research and Review}

ISSN: 2581-8341

Volume 04 Issue 03 March 2021

DOI: 10.47191/ijesrr/V4-i3-05, Impact Factor: 5.825

IJCSRR@ 2021

www.ijcsrr.org

of software. The Swiss Cheese test case generation method proposed in this paper is designed to perform both positive and negative testing that also reveal the vulnerability of web services. This integrated development process is implemented in a case study. The experimental evaluation demonstrates the effectiveness of this approach. It also reveals that the Swiss Cheese negative testing detects even more faults than positive testing and thus significantly reduces the vulnerability of web services (Tsai et al., 2005).

Service development certainly uses a good computer network security system. Computer network security system is a way to prevent or protect and identify unauthorized users (intruders) to access a network in order to avoid various threats without any obstacles (Senthil Kumar \& Muthukumar, 2018). In addition, security system is also used to monitor and prevent unauthorized access, misuse of information, modification and even deletion of important data on a server. It is also stated by Souleyand Abubakar (2018) that the threats can be categorized into two types i.e. internal and external threats. Internal threat could exist intentionally or accidentally. External threat could be tapping system from others. The threat forms of computer network become varied day by day. Therefore, the thing that should be kept in mind is no network of computers that is anti-tapping or no network is completely safe from various threats from people who have bad intention. Because the nature of network has communication openly and the information can be accessed also by people who intend to misuse them. Therefore, security system is highly needed to secure the data in a computer network. The precautions to protect the network arethe duty of network administrator (Iskandar et al., 2019).

\section{RESEARCH METHODOLOGY}

This literature review focuses on the web-based management system information and service development. The review process began with a search engine, Google scholar and IEEE, to search for articles with keywords: "web-based management system information for services development". The search ranged was from 2001-2019 and a total of 40 articles were identified.

The criteria for inclusion in this study were as follows:

a. qualitative and quantitative results of relationship between web-based management system information and services development.

b. the research was conducted in several countries.

c. the research used English language.

d. dissertation and thesis are excluded.

Table 1. The Web-Based Management System Information for Services Development

\begin{tabular}{|c|c|c|c|c|c|c|}
\hline \multirow[b]{2}{*}{$\begin{array}{l}\text { Author(s) } \\
\text { and year }\end{array}$} & \multirow[b]{2}{*}{ Title } & \multirow[b]{2}{*}{ Country } & \multirow[b]{2}{*}{$\begin{array}{l}\text { Methods } \\
\text { Research }\end{array}$} & \multirow[b]{2}{*}{$\begin{array}{l}\text { Sampl } \\
\text { e }\end{array}$} & \multicolumn{2}{|l|}{ Result } \\
\hline & & & & & $\begin{array}{l}\text { The Web-Based } \\
\text { Management } \\
\text { System } \\
\text { Information }\end{array}$ & vice Development \\
\hline $\begin{array}{l}\text { Abdullah, et } \\
\text { al (2018) }\end{array}$ & $\begin{array}{lr}\text { A } & \text { Slack-Based } \\
\text { Measures } & \text { within } \\
\text { Group } & \text { Common } \\
\text { Benchmarking } & \text { using } \\
\text { DEA for Improving } \\
\text { the } \\
\text { Performance } \\
\text { Departments } \\
\text { Universitas } \\
\text { Malikussaleh }\end{array}$ & Indonesia & $\begin{array}{l}\text { Mathematical } \\
\text { programming } \\
\text { methods }\end{array}$ & $\begin{array}{l}522 \text { stu } \\
\text { of } \\
\text { Universi } \\
\text { Malikus } \\
\text { h }\end{array}$ & $\begin{array}{ll}\text { dent } & \text { Data Envelopment } \\
\text { Analysis (DEA) } \\
\text { tas }\end{array}$ & $\begin{array}{l}\text { DEA model can be applied } \\
\text { to ensure quality of data in } \\
\text { the process of efficiency } \\
\text { measurement }\end{array}$ \\
\hline $\begin{array}{l}\text { Azizyan, } \\
\text { Constandache } \\
\text {, and Roy }\end{array}$ & $\begin{array}{lr}\text { Surround } & \text { Sense: } \\
\text { Mobile } & \text { Phone } \\
\text { Localization } & \text { via }\end{array}$ & USA & $\begin{array}{l}\text { Mobile } \\
\text { computing }\end{array}$ & 51 stores & $\begin{array}{l}\text { Surroundsense: } \\
\text { Fingerprint }\end{array}$ & $\begin{array}{l}\text { Surroundsense is } \\
\text { sophistiscated } \\
\text { classification, and better }\end{array}$ \\
\hline
\end{tabular}




\section{International Journal of Current Science Research and Review}

ISSN: 2581-8341

Volume 04 Issue 03 March 2021

DOI: 10.47191/ijesrr/V4-i3-05, Impact Factor: 5.825

IJCSRR@ 2021

WwW.ijcsrr.org

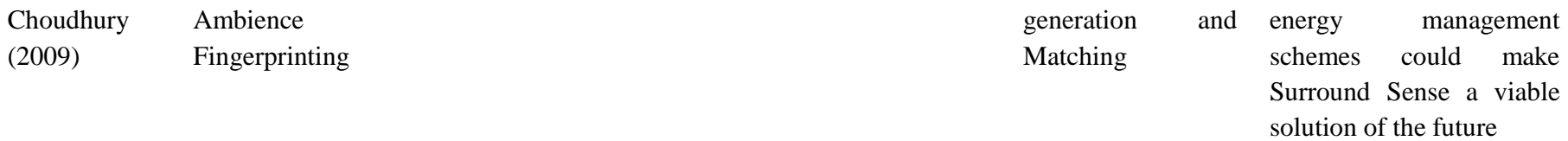

Bahagia, et al Sistem Informasi Data $\quad$ Indonesia $\quad$ Designing $\quad$ Communitie Web-based $\quad$ Information systems can

Korban Kebencanaan

Berbasis WEB
Data Flow $\mathrm{s}$ who are information system

Diagrams and victims of using PHP program

Designing disasters and database

Entity mySQL

Diagrams

\begin{tabular}{llr}
\hline Dong, et al & Business \\
(2008) & & Performance, \\
& Business Strategy, \\
& and Information \\
& System Strategic \\
& Alignment: An \\
& Empirical Study on \\
& Chinese Firm
\end{tabular}

\section{China}

Conceptualizin

$\mathrm{g}$ and directing

strategic

management

of information

technology

$\begin{array}{ll}126 & \text { Information } \\ \text { questionnair } & \text { System Strategic } \\ \text { es } & \text { Alignment }\end{array}$

es

\begin{tabular}{|c|c|c|c|c|c|}
\hline $\begin{array}{l}\text { Fauzy, et al } \\
(2018)\end{array}$ & $\begin{array}{l}\text { Registration System } \\
\text { and UTM Games } \\
\text { Decision Using the } \\
\text { Website Application }\end{array}$ & $\begin{array}{l}\text { Indonesia- } \\
\text { Malaysia }\end{array}$ & $\begin{array}{l}\text { Web } \\
\text { Programming }\end{array}$ & $\begin{array}{l}\text { Students } \\
\text { which are } \\
\text { registration } \\
\text { system and } \\
\text { UTM games }\end{array}$ & $\begin{array}{l}\text { Information } \\
\text { System using web } \\
\text { programming }\end{array}$ \\
\hline
\end{tabular}

Information System using web programming can be used in problem solving are also carried out to ensure that the proposed system can be developed seamlessly and meets the system requirements

\begin{tabular}{|c|c|c|c|c|c|c|}
\hline $\begin{array}{l}\text { Iskandar, et al } \\
\text { (2019) }\end{array}$ & $\begin{array}{l}\text { Implementing DMZ } \\
\text { in Improving Network } \\
\text { Security of Web } \\
\text { Testing in STMIK } \\
\text { AKBA }\end{array}$ & Indonesia & $\begin{array}{l}\text { Research and } \\
\text { Development } \\
\text { using } \\
\text { descriptive } \\
\text { method }\end{array}$ & $\begin{array}{l}\text { User } \\
\text { Internet in } \\
\text { STMIK } \\
\text { AKBA }\end{array}$ & $\begin{array}{l}\text { DMZ Network } \\
\text { Security of web }\end{array}$ & $\begin{array}{l}\text { DMZ Network Security of } \\
\text { web is safe and } \\
\text { inaccessible by intruders }\end{array}$ \\
\hline $\begin{array}{l}\text { King and } \\
\text { Brown (2007) }\end{array}$ & $\begin{array}{l}\text { Fix My Street or Else: } \\
\text { Using the Internet to } \\
\text { Voice Local Public } \\
\text { Service Concern }\end{array}$ & England & $\begin{array}{l}\text { Interview and } \\
\text { survey }\end{array}$ & $\begin{array}{l}90 \\
\text { Responden }\end{array}$ & $\begin{array}{l}\text { Fix My Street.com } \\
\text { (FMS) }\end{array}$ & $\begin{array}{l}\text { The FMS developer also } \\
\text { made the point that FMS } \\
\text { can improve council } \\
\text { efficiency by enabling } \\
\text { posters }\end{array}$ \\
\hline $\begin{array}{l}\text { Lazim, et al } \\
\text { (2018) }\end{array}$ & $\begin{array}{l}\text { Information } \\
\text { Management and } \\
\text { PSM Evaluation } \\
\text { System }\end{array}$ & Malaysia & $\begin{array}{l}\text { Research and } \\
\text { Development }\end{array}$ & $\begin{array}{l}\text { Student and } \\
\text { teacher }\end{array}$ & $\begin{array}{l}\text { Web-based the } \\
\text { TEAMMATES } \\
\text { system }\end{array}$ & $\begin{array}{l}\text { This system solves } \\
\text { problem more efficient and } \\
\text { effective }\end{array}$ \\
\hline $\begin{array}{l}\mathrm{Li}, \quad \text { et al } \\
(2002)\end{array}$ & $\begin{array}{l}\text { Measuring } \\
\text { Based } \\
\text { Quality }\end{array}$ & Singapore & $\begin{array}{l}\text { Research and } \\
\text { Development } \\
\text { using } \\
\text { questionnaire } \\
\text { design }\end{array}$ & $\begin{array}{l}\text { Customer } \\
\text { service and } \\
\text { traditional } \\
\text { communicat } \\
\text { ion }\end{array}$ & $\begin{array}{l}\text { Web-based the } \\
\text { SERQUAL model }\end{array}$ & $\begin{array}{l}\text { Web-based the SERQUAL } \\
\text { model can improve } \\
\text { achieve } \\
\text { satisfaction }\end{array}$ \\
\hline
\end{tabular}




\section{International Journal of Current Science Research and Review}

ISSN: 2581-8341

Volume 04 Issue 03 March 2021

DOI: 10.47191/ijesrr/V4-i3-05, Impact Factor: 5.825

IJCSRR@ 2021

WwW.ijcsrr.org

\begin{tabular}{|c|c|c|c|c|c|c|}
\hline $\begin{array}{l}\text { LiKamWa, et } \\
\text { al (2013) }\end{array}$ & 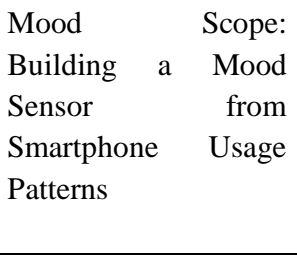 & China & $\begin{array}{l}\text { Research and } \\
\text { Development } \\
\text { using the } \\
\text { circumplex } \\
\text { mood model }\end{array}$ & $\begin{array}{l}32 \\
\text { participants }\end{array}$ & $\begin{array}{l}\text { The } \\
\text { implementation of } \\
\text { a mood sensor in } \\
\text { the Mobile device } \\
\text { (Mood Scope API) }\end{array}$ & $\begin{array}{l}\text { The implementation of a } \\
\text { mood sensor in the Mobile } \\
\text { device (Mood Scope API) } \\
\text { can built and enhance } \\
\text { custom mood-enabled } \\
\text { application }\end{array}$ \\
\hline $\begin{array}{l}\text { Liu, et al } \\
(2015)\end{array}$ & $\begin{array}{l}\text { Design of research } \\
\text { Management System } \\
\text { Based on Workflow } \\
\text { and Rapid } \\
\text { Development } \\
\text { Platform Technology }\end{array}$ & China & $\begin{array}{l}\text { Research and } \\
\text { Development } \\
\text { used The } \\
\text { project } \\
\text { management } \\
\text { workflow of a } \\
\text { certain } \\
\text { research } \\
\text { institution } \\
\text { includes } \\
\text { application, } \\
\text { execution, and } \\
\text { acceptance }\end{array}$ & $\begin{array}{l}\text { Unit user or } \\
\text { managemen } \\
\mathrm{t} \\
\text { specificatio } \\
\mathrm{n}\end{array}$ & $\begin{array}{l}\text { Web-based system } \\
\text { development } \\
\text { process based on } \\
\text { rapid development } \\
\text { platform } \\
\text { technology }\end{array}$ & $\begin{array}{l}\text { The system can help raise } \\
\text { the scientific research } \\
\text { work level of scientific } \\
\text { institute }\end{array}$ \\
\hline $\begin{array}{l}\text { Lu, et al } \\
(2012)\end{array}$ & $\begin{array}{l}\text { Stress Sense: } \\
\text { Detecting Stress in } \\
\text { Unconstrained } \\
\text { Acoustic } \\
\text { Environment Using } \\
\text { Smartphones }\end{array}$ & USA & $\begin{array}{l}\text { Research and } \\
\text { Development } \\
\text { used Smart } \\
\text { Phones }\end{array}$ & $\begin{array}{l}14 \\
\text { participant }\end{array}$ & $\begin{array}{lc}\begin{array}{l}\text { Gaussian } \\
\text { Models }\end{array} & \text { Mixture } \\
\text { (GMMs) } \\
\text { with } & \text { diagonal } \\
\text { covariance matrix }\end{array}$ & $\begin{array}{l}\text { Stress Sense application } \\
\text { release on an adaptive } \\
\text { pipeline that uses the self- } \\
\text { train model for speaker } \\
\text { adaption and the } \\
\text { supervised adaption model } \\
\text { for environment adaption }\end{array}$ \\
\hline $\begin{array}{l}\text { Molnár and } \\
\text { Ádám (2019) }\end{array}$ & $\begin{array}{lr}\text { Design } & \text { and } \\
\text { Architectural Issues of } \\
\text { Contemporary Web- } \\
\text { Based Information } \\
\text { Systems }\end{array}$ & Hungaria & $\begin{array}{l}\text { Research and } \\
\text { Development } \\
\text { used web- } \\
\text { based } \\
\text { information } \\
\text { system } \\
\end{array}$ & $\begin{array}{l}\text { User } \\
\text { (clients) }\end{array}$ & $\begin{array}{l}\text { Web-based } \\
\text { information system } \\
\text { (WIS) }\end{array}$ & $\begin{array}{l}\text { WIS be able to formulate a } \\
\text { practical development } \\
\text { method for achievement of } \\
\text { WIS by organization } \\
\text { making the most of Web }\end{array}$ \\
\hline $\begin{array}{l}\text { Noni, et al } \\
(2018)\end{array}$ & $\begin{array}{lr}\text { The Development of } \\
\text { Research } \\
\text { Management } \\
\text { Information System } \\
\text { Based on } \\
\text { Universitas } & \text { Negeri } \\
\text { Makasar } & \end{array}$ & Indonesia & $\begin{array}{l}\text { Research and } \\
\text { Development }\end{array}$ & Lecturer & $\begin{array}{l}\text { Web-Based the } \\
\text { Academic } \\
\text { Information } \\
\text { System (SIA) }\end{array}$ & $\begin{array}{l}\text { 1. This system will provide } \\
\text { information to the general } \\
\text { public about the research } \\
\text { developed }\end{array}$ \\
\hline $\begin{array}{ll}\text { Reza } & \text { Kiani } \\
(1998) & \end{array}$ & $\begin{array}{l}\text { Marketing } \\
\text { opportunities in the } \\
\text { world }\end{array}$ & Greenlands & $\begin{array}{l}\text { Research and } \\
\text { Development }\end{array}$ & Advertiser & $\begin{array}{l}\text { Model for } \\
\text { advertising on the } \\
\text { web }\end{array}$ & $\begin{array}{l}\text { Access information will be } \\
\text { effective }\end{array}$ \\
\hline $\begin{array}{ll}\text { Satria, et al } \\
(2018)\end{array}$ & $\begin{array}{lr}\text { Final } & \text { Project } \\
\text { Consultation } & \\
\text { Information } & \text { System } \\
\text { Integrated } & \\
\text { Notification } & \text { System } \\
\text { Based On } & \text { SMS } \\
\text { Gateway } & \end{array}$ & Indonesia & $\begin{array}{l}\text { System } \\
\text { analysis and } \\
\text { system design }\end{array}$ & $\begin{array}{l}\text { Student and } \\
\text { Lecturer }\end{array}$ & $\begin{array}{l}\text { System based on } \\
\text { SMS gateway }\end{array}$ & $\begin{array}{ll}\text { Information } & \text { system is } \\
\text { integrated } & \text { with the } \\
\text { notification } & \text { system using } \\
\text { SMS } & \end{array}$ \\
\hline
\end{tabular}




\section{International Journal of Current Science Research and Review}

ISSN: 2581-8341

Volume 04 Issue 03 March 2021

DOI: 10.47191/ijcsrr/V4-i3-05, Impact Factor: 5.825

IJCSRR@ 2021

WwW.ijcsrr.org

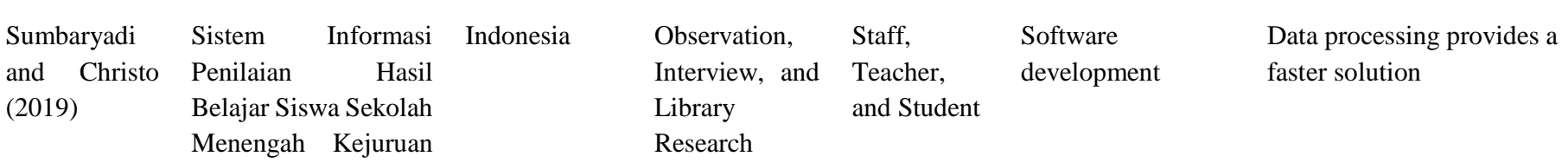

(SMK) Berbasis WEB

$\begin{array}{lllll}\text { Susanto, et al } & \text { Pengembangan } & \text { Indonesia } & \text { Research and } & \text { Principal, } \\ \text { (2015) } & \text { Sistem Informasi } & \text { development } & \text { Educator } & \text { Information } \\ & \text { Manajemen Pendidik } & & \text { and } & \text { System } \\ & \text { dan Tenaga } & & \text { education } & \text { Development } \\ & \text { Kependidikan } & & \text { staff } & \end{array}$

Information system
application that makes it
easy for school
management, educators
and education personnel to
manage transactional data
and produce information
that supports the needs of
school management in
making decisions
Data information systems
can process disaster data
effectively and efficiently

Zulfan, et al Indonesia

(2017)

Indonesia

$\begin{array}{lll}\begin{array}{l}\text { The } \\ \text { community } \\ \text { affected by } \\ \text { the disaster }\end{array} & \begin{array}{l}\text { Web-based disaster } \\ \text { system using PHP } \\ \text { and mySQL }\end{array} & \begin{array}{l}\text { Data information systems } \\ \text { can process disaster data } \\ \text { effectively and efficiently }\end{array} \\ \end{array}$

\section{RESULTS AND DISCUSSION}

This section reports the main findings of the reviewed articles. Analysis shows that most articles focus on web-based management information system for services development. Articles that have been reviewed are those in which research was conducted in several countries.

Based on the articles reviewed as outlined in Table 1, there are various ways web-based management information systems are used to develop services. But there is little to explain the service of development information. The research method used differs from article to article. The most widely used service development method is the web-based information system (Bahagia et al., 2017; Fauzy et al., 2018; Li et al., 2002; Liu et al., 2015; Molnár \& Ádám, 2019; Noni et al., 2018; Reza Kiani, 1998; Zulfan et al., 2017) While information about service development is still little explained and information on the use of services is spread across a variety of services, such as in the fields of education, social, and business. Considering the development of information technology and the growing amount of information about the environment, it becomes necessary for an environmental management organization to utilize an information system that will manage all relevant environmental information and also will be used as a tool for a better and more efficient management of the protected area and the natural resources (Graham, Amos, \& Plumptre, 2003) Research on the influence of Web-Based Management Information Systems for Services Development has been carried out in various organizations and in various countries. Table 1 shows that research has been carried out in schools, universities, and companies. The results of the study largely showed a positive and significant effect between Web-Based Management Information Systems for Services Development. Based on the articles that have been reviewed, most of the articles discuss web-based management information systems, while only a few discussed service development information.

As with research, this review has limitations. First, dissertations and theses are not included in the review because they can cause publication bias in the results. Second, the limited articles in accordance with web-based management information systems for services development. Finally, there is no single measure that can compare across studies. 


\section{International Journal of Current Science Research and Review}

ISSN: 2581-8341

Volume 04 Issue 03 March 2021

DOI: 10.47191/ijesrr/V4-i3-05, Impact Factor: 5.825

IJCSRR@ 2021

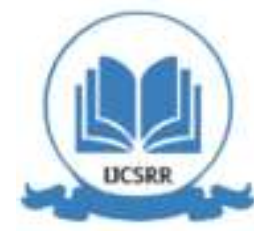

Www.ijesrr.org

\section{CONCLUSION}

The conclusion of this literature review is that there is a positive and significant influence of web-based management information systems for service development and future research will help to help organizations evaluate the quality of their web-based services, design improvements and ultimately embed their websites into future services. From the results of literature review from various fields and various countries, it is clear that the information management system is very influential in terms of public services. If the public service process is done manually, it will certainly spend a lot of time, cost, and the data obtained is not necessarily accurate. Web-based information management system for services development certainly requires adequate human resources in developing the system. This is because web technology has different types depending on the needs, users, and wide range, so that it can obtain accurate, fast, effective and efficient data. If not handled by someone who is reliable, of course, this website will not be good and will even cause confusion to users, so the purpose of the system settings are not as expected.

\section{REFERENCES}

1. Abdullah, D., Zarlis, M., Napitupulu, D., Hartono, H., Sriadhi, S., Erliana, C. I., . . Rahim, R. (2018). A Slack-Based Measures within Group Common Benchmarking using DEA for Improving the Efficiency Performance of Departments in Universitas Malikussaleh. Paper presented at the MATEC Web of Conferences.

2. Afrina, M., \& Ibrahim, A. (2012). Pengembangan Model Sistem Informasi Perpustakaan Dengan Teknologi Informasi Berbasis Wireless Aplication Protocol (WAP) Pada Universitas Sriwijaya. Jurnal Sistem Informasi, 4(1).

3. Afrina, M., \& Ibrahim, A. (2015). Pengembangan Sistem Informasi SMS Gateway Dalam Meningkatkan Layanan Komunikasi Sekitar Akademika Fakultas Ilmu Komputer Unsri. Jurnal Sistem Informasi, 7(2).

4. Anggadini, S. D. (2013). Analisis sistem informasi manajemen berbasis komputer dalam proses pengambilan keputusan. Majalah Ilmiah UNIKOM.

5. Azizyan, M., Constandache, I., \& Roy Choudhury, R. (2009). Surround Sense: Mobile Phone Localization Via Ambience Finger Printing. Paper presented at the Proceedings of the 15th annual international conference on Mobile computing and networking.

6. Bahagia, B., Satria, D., \& Ahmadian, H. (2017). Perancangan Sistem Informasi Manajemen Data Korban Bencana Berbasis Mobile Android. Jurnal Ekonomi Manajemen dan Akuntansi (JEMSI), 3(2). doi: 10.32672/jemsi.v3i2.293

7. Boey, R., Ang, T., \& Liew, C. (2008). An interactive web-based wedding planner with comparative analysis decision support system. WSEAS Transactions on Information Science and Applications, 5(3), 211-220.

8. Dong, X., Liu, Q., \& Yin, D. (2008). Business performance, business strategy, and information system strategic alignment: An empirical study on Chinese firms. Tsinghua science and Technology, 13(3), 348-354. doi: 10.1016/S10070214(08)70056-7

9. Fauzi, R. (2016). Sistem Informasi Pemesanan Wedding Organizer Di Joen Salon Berbasis Website. Universitas Komputer Indonesia.

10. Fauzy, F. A. A., Shah, Z. A., Saedudin, R. R., Kasim, S., Azadin, A. A., Ahmar, A. S., \& Hidayat, R. (2018). Registration System and UTM Games Decision Using the Website Application. Int. J. Eng. Technol, 7(2.2), 45-47.

11. Graham, J., Amos, B., \& Plumptre, T. W. (2003). Governance principles for protected areas in the 21st century: Institute on Governance, Governance Principles for Protected Areas Ottawa.

12. Gueorguiev, I., Dimitrova, S., Komitska, M., Traykov, H., \& Spassov, K. (2005). Balanced scorecard based management information system-a potential for public monitoring and good governance advancement. The Electronic Journal of eGovernment, 3(1), 29-38.

13. Iskandar, A., Virma, E., \& Ahmar, A. S. (2019). Implementing DMZ in Improving Network Security of Web Testing in STMIK AKBA. arXiv preprint arXiv:1901.04081.

14. King, S. F., \& Brown, P. (2007). Fix my street or else: using the internet to voice local public service concerns. Paper presented at the Proceedings of the 1st international conference on Theory and practice of electronic governance.

15. Kosasish, A. (2009). Otomasi Perpustakaan Sekolah: Sebuah Pengenalan. Perpustakaan Universitas Negeri Malang (UM), 1-13. 


\section{International Journal of Current Science Research and Review}

ISSN: 2581-8341

Volume 04 Issue 03 March 2021

DOI: 10.47191/ijcsrr/V4-i3-05, Impact Factor: 5.825

IJCSRR@ 2021

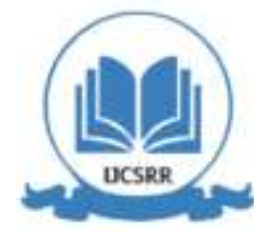

WwW.ijcsrr.org

16. Kouziokas, G. N. (2016). Technology-based management of environmental organizations using an Environmental Management Information System (EMIS): Design and development. Environmental Technology \& Innovation, 5, $106-$ 116.

17. Lazim, D., Shah, Z. A., Saedudin, R. R., Kasim, S., Azadin, A. A., Hidayat, R., \& Ansari Saleh Ahmar, I. A. (2018). Information Management and PSM Evaluation System. Int. J. Eng. Technol, 7(1.6), 17-19.

18. Li, Y., Tan, K., \& Xie, M. (2002). Measuring web-based service quality. Total quality management, 13(5), 685-700. doi: $10.1080 / 0954412022000002072$

19. LiKamWa, R., Liu, Y., Lane, N. D., \& Zhong, L. (2013). Moodscope: Building a mood sensor from smartphone usage patterns. Paper presented at the Proceeding of the 11th annual international conference on Mobile systems, applications, and services.

20. Liu, Y., Yao, Y., Zhang, X., Liu, B., \& Ding, C. (2015). Design of research management system based on workflow and rapid development platform technology. Paper presented at the 2015 International Conference on Estimation, Detection and Information Fusion (ICEDIF).

21. Lu, H., Frauendorfer, D., Rabbi, M., Mast, M. S., Chittaranjan, G. T., Campbell, A. T., . . . Choudhury, T. (2012). Stresssense: Detecting stress in unconstrained acoustic environments using smartphones. Paper presented at the Proceedings of the 2012 ACM Conference on Ubiquitous Computing.

22. Meriyanti, M. (2013). Sistem Informasi Pemesanan Dan Promosi Paket Pernikahan Pada Wedding Organizer Sanggar Rias Dan Salon Shopie. Universitas Komputer Indonesia.

23. Molnár, B., \& Ádám, T. (2019). Design and architectural issues of contemporary web-based information systems.

24. Najiyah, I., \& Suharyanto, S. (2017). Sistem Informasi Wedding Planner Berbasis Web. JITK (Jurnal Ilmu Pengetahuan Dan Teknologi Komputer), 3(1), 79-86.

25. Noni, N., Ihsan, N., \& Ahmar, A. S. (2018). The Development of Research Management Information System Based on Web at Universitas Negeri Makassar. Paper presented at the Journal of Physics: Conference Series.

26. Noran, O. (2003). A mapping of individual architecture frameworks (GRAI, Pera, C4ISR, CIMOSA, Zachman, ARIS) onto GERAM Handbook on enterprise architecture (pp. 65-210): Springer.

27. Noran, O. (2005). A systematic evaluation of the C4ISR AF using ISO15704 Annex A (GERAM). Computers in Industry, 56(5), 407-427.

28. Nowduri, S. (2011). Management information systems and business decision making: review, analysis, and recommendations. Journal of Management and Marketing Research, 7, 1.

29. Pasley, J. (2005). How BPEL and SOA are changing web services development. IEEE Internet Computing, 9(3), 60-67.

30. Reza Kiani, G. (1998). Marketing opportunities in the digital world. Internet research, 8(2), 185-194. doi: $10.1108 / 10662249810211656$

31. Satria, D., Zulfan, Z., Yana, S., \& Yulizar, Y. (2018). Perancangan Sistem Informasi Manajemen Pembelian dan Penjualan Komoditas Perkebunan Masyarakat Pada UD. Bintang Baru. Jurnal Ekonomi Manajemen dan Akuntansi (JEMSI), 4(1). doi: 10.32672/jemsi.v4i1.591

32. SenthilKumar, P., \& Muthukumar, M. (2018). A Study on Firewall System, Scheduling and Routing using pfsense Scheme. Paper presented at the 2018 International Conference on Intelligent Computing and Communication for Smart World (I2C2SW).

33. Setiadi, T., \& Muryanti, A. S. (2009). Pembangunan Sistem Informasi Layanan Pelanggan Di Pdam Tirtamarta Berbasis SMS. Jurnal Informatika Ahmad Dahlan, 2(1), 103872.

34. Setiajati, A. (2017). Implementasi Sistem Informasi Jasa Wedding Organizer Dengan Fitur Pemilihan Paket Otomatis Menggunakan Algoritma Greedy. University of Muhammadiyah Malang.

35. Standing, C., Jackson, P., Chen, A. J., Boudreau, M. C., \& Watson, R. T. (2008). Information systems and ecological sustainability. Journal of Systems and Information Technology.

36. Sumbaryadi, A., \& Christo, P. (2019). Sistem Informasi Penilaian Hasil Belajar Siswa Sekolah Menengah Kejuruan (SMK) Berbasis WEB. JSiI (Jurnal Sistem Informasi), 6(1), 48-53. 


\section{International Journal of Current Science Research and Review}

ISSN: 2581-8341

Volume 04 Issue 03 March 2021

DOI: 10.47191/ijesrr/V4-i3-05, Impact Factor: 5.825

IJCSRR@ 2021

WWW.ijcsrr.org

37. Suryandani, F. (2016). Pengembangan Sistem Informasi Akademik Berbasis Web Sebagai Sistem Pengolahan Nilai Siswa Di Smk Negeri 1 Kudus. Universitas Sebelas Maret.

38. Susanto, H. M., Mantja, W., Bafadal, I., \& Sonhadji, A. (2015). Developing Management Information System for Teachers and Education Staff. Jurnal Pendidikan Humaniora, 3(2), 93-105.

39. Tomlinson, B. (2012). Greening through IT: information technology for environmental sustainability: MIT Press.

40. Tsai, W.-T., Wei, X., Chen, Y., Xiao, B., Paul, R., \& Huang, H. (2005). Developing and assuring trustworthy web services. Paper presented at the Proceedings Autonomous Decentralized Systems, 2005. ISADS 2005.

41. Wardana, T. I., \& Aribowo, E. (2013). Perancangan dan implementasi sistem informasi manajemen kegiatan Masjid studi kasus: Masjid Jogokariyan Yogyakarta. Jurnal Sarjana Teknik Informatika, 1(1), 119-128.

42. Yang, Y., Lee, P. K., \& Cheng, T. (2016). Continuous improvement competence, employee creativity, and new service development performance: A frontline employee perspective. International Journal of Production Economics, 171,275 288. doi: 10.1016/j.ijpe.2015.08.006

43. Zulfan, Z., Bahagia, B., Ahmadian, H., \& Satria, D. (2017). Sistem Informasi Data Korban Kebencanaan Berbasis WEB. Paper presented at the Prosiding Seminar Nasional USM.

Cite this Article: Eny Setyawati, Hasan Hariri (2021). Web-Based Management Information System for Services

Development: A Literature Review. International Journal of Current Science Research and Review, 4(3), 175-185 